\title{
PENYELESAIAN SENGKETA WAKAF MELALUI \\ JALUR LITIGASI DAN NON-LITIGASI
}

\author{
Muhammad Rifqi Hidayat \\ Dosen Fakultas Ekonomi dan Bisnis Islam UIN Antasari | rifqifebi@uin-antasari.ac.id
}

\section{Parman Komarudin}

Dosen Program Studi Hukum Ekonomi Syariah | Fakultas Studi Islam Universitas Islam Kalimantan MAB Banjarmasin Indonesia|Parmankomarudinfsi79@gmail.com

\begin{abstract}
Land endowments, if carried out without a good and correct administrative process, are prone to produce disputes in the future. We conduct this research to describe how the endowments dispute resolution process is through litigation and non-litigation channels in accordance with the applicable laws and regulations in Indonesia. This research is a combination of normative and empirical legal research. We collect primary data from legislation regarding endowments and examples of endowments disputes, while secondary data comes from studies and legal opinions on endowments disputes. The data obtained is then analyzed qualitatively. The results of the study show that settlement of property endowments disputes is carried out in several stages which should be carried out stratifically, namely deliberation, mediation, arbitration, and finally through the court.
\end{abstract}

Keywords: Dispute resolution, Endowments, Litigation, Non-litigation

\begin{abstract}
Abstrak
Wakaf tanah yang dilakukan tanpa proses administrasi yang baik dan benar rentan melahirkan sengketa di kemudian hari. Maka riset ini dilakukan untuk mendeskripsikan bagaimana proses penyelesaian sengketa wakaf tersebut melalui jalur litigasi dan non-litigasi sesuai dengan peraturan perundangan yang berlaku di Indonesia. Riset ini adalah penelitian kombinasi antara penelitian hukum normatif dan empiris. Data primer bersumber dari peraturan perundangan mengenai wakaf dan contoh kasus sengketa wakaf, sedangkan data sekunder berasal dari penelitian-penelitian dan pendapat hukum tentang sengketa wakaf. Data yang didapatkan kemudian dianalisa secara kualitatif. Hasil penelitian menunjukkan bahwa penyelesaian sengketa harta wakaf ditempuh dengan beberapa tahapan yang seyogyanya dilakukan secara stratifikatif, yaitu musyawarah, mediasi, arbitrase, dan terakhir melalui pengadilan.
\end{abstract}

Kata kunci: Litigasi, Non-litigasi, Penyelesaian Sengketa, Wakaf 


\section{PENDAHULUAN}

Islam telah memberikan ribuan kesempatan bagi pemeluknya untuk mendekatkan diri kepada Tuhan, salah satunya yaitu melalui wakaf ${ }^{1}$. Walaupun di dalam al-Qur'an tidak dijelaskan secara tegas mengenai anjuran untuk melakukan wakaf, namun beberapa ayat menganjurkannya secara tersirat dengan menggunakan istilah infaq demi kepentingan umum ${ }^{2}$. Surah Ali Imron ayat 92 misalnya, Allah menyatakan bahwa manusia tidak akan memperoleh kebaikan kecuali jika ia menyedekahkan sebagian harta yang disenanginya. Adapun bunyi dari surah Ali Imron ayat 92 tersebut yaitu:

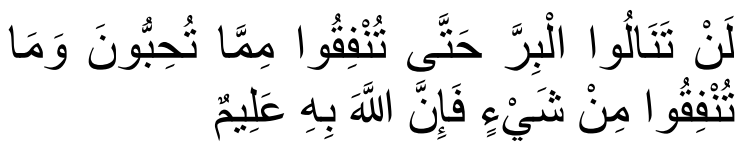

Artinya: "Kamu sekali-kali tidak sampai kepada kebajikan (yang
sempurna), sebelum kamu
menafkahkan sehahagian harta
yang kamu cintai. Dan apa saja
yang kamu nafkahkan maka
sesungguhnya
mengetahuinya."

Kemudian dalam Hadis riwayat Abu Hurairah disebutkan bahwasanya shadaqah jariyah akan memberikan pahala yang

1 Bashlul Hazami, "Peran Dan Aplikasi Wakaf Dalam Mewujudkan Kesejahteraan Umat Di Indonesia," Analisis 16, no. 1 (2016): 174, http://ejournal.radenintan.ac.id/index.php/analisis/ar ticle/view/742.

2 Amirul Bakhri and Srifariyati, "Peran Wakaf Produktif Dalam Pemberdayaan Ekonomi," Madaniyah 1, no. 12 (2017): 134, https://journal.stitpemalang.ac.id/index.php/madani yah/article/view/67. tidak akan putus kepada manusia walaupun dia telah meninggal dunia. Matan dari hadis tersebut yaitu ${ }^{3}$ :

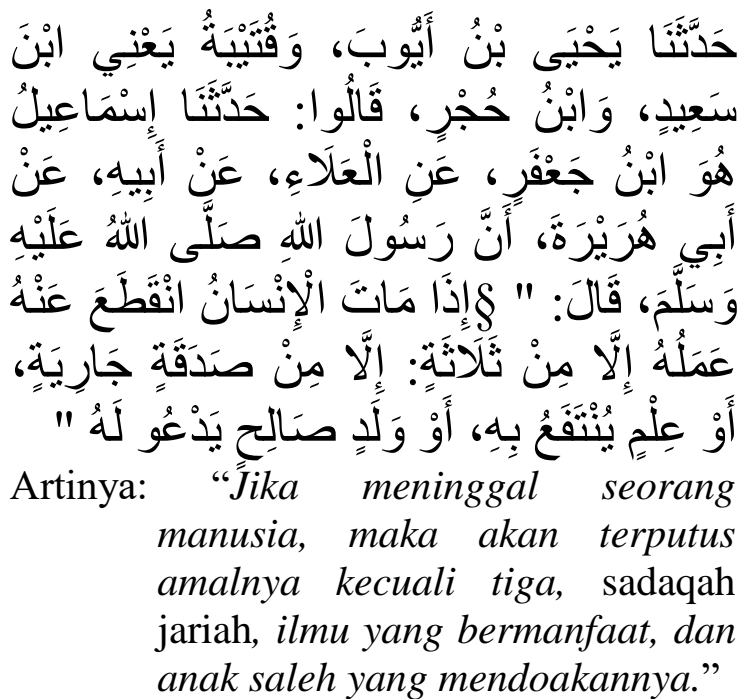

Seiring perkembangan zaman, muncul berbagai macam persengketaan mengenai harta wakaf. Khususnya pada wakaf tanah yang pada zaman dahulu tidak jelas administrasi maupun dokumentasinya 4 . Maka disini tim penulis mencoba untuk menelusuri contoh kasus sengketa wakaf berikut proses penyelesaiannya di Indonesia baik dari jalur litigasi maupun non-litigasi berdasarkan peraturan perundangan yang berlaku. Melalui riset ini, dapat diketahui penyebab utama persengketaan wakaf tersebut agar masyarakat bisa menghindarinya, sekaligus sebagai sumber referensi bagi masyarakat yang terlibat dalam kasus persengketaan wakaf di masa yang akan datang.

\footnotetext{
${ }^{3}$ Muslim bin Hajjaj, Sahih Muslim (Beirut: Dar alKutub al-Ilmiyah, 1991), 1255.

${ }^{4}$ Upi Komariah, "Penyelesaian Sengketa Wakaf Di Pengadilan Agama," Jurnal Hukum dan Peradilan 3, no. 2 (2014): 118.
} 
Sepanjang pengetahuan tim penulis, ini adalah riset pertama yang merangkum proses penyelesaian sengketa wakaf melalui jalur litigasi dan non-litigasi. Selain artikel ini, terdapat beberapa riset lainnya yang juga membahas mengenai sengketa wakaf. ${ }^{5}$ misalnya, menerbitkan riset dengan judul "Penyelesaian Sengketa Wakaf di Indonesia: Pendekatan Sejarah Sosial Hukum Islam", yang melakukan penelitian historis mengenai kasus-kasus permasalahan sengketa wakaf yang terjadi pada awal periode Islam maupun kontemporer serta penyelesaiannya pada dekade-dekade yang lalu. ${ }^{6}$ menulis mengenai penyelesaian sengketa wakaf di Pengadilan Agama Jakarta Selatan, yang berfokus pada prosedur yang dilakukan Pengadilan Agama dalam menangani kasus sengketa wakaf. 7 juga melakukan penelitian dengan judul "Sengketa Tanah Wakaf dan Strategi Penyelesaiannya" yang berhasil menemukan faktor penyebab konflik wakaf berdasarkan teori resolusi konflik Ralf Dahrendorf serta strategi penyelesaiannya berdasarkan sudut pandang peraturan-peraturan wakaf. Maka

\footnotetext{
${ }^{5}$ Ibrahim Siregar, "Penyelesaian Sengketa Wakaf Di Indonesia: Pendekatan Sejarah Sosial Hukum Islam," MIQOT 36, no. 1 (2012).

6 Syufa'at, "Penerapan Prosedur Mediasi Dalam Penyelesaian Sengketa Wakaf Di Pengadilan Agama," Volksgeist: Jurnal Ilmu Hukum dan Konstitusi 1, no. 1 (2018): 21-36.

7 Nur Fadhilah, "Sengketa Tanah Wakaf Dan Strategi Penyelesaiannya," de Jure 3, no. 1 (2011).
}

dengan demikian, dapat dilihat letak perbedaan riset yang dilakukan oleh tim penulis dalam artikel ini jika dibandingkan dengan riset lainnya, yaitu bahwa artikel ini membahas penyelesaian sengketa wakaf dari sudut pandang besar melalui jalur litigasi dan non-litigasi.

Riset ini sendiri tergolong ke dalam jenis penelitian kombinasi antara penelitian hukum normatif dan empiris, yaitu penelitian normatif yang perlu didukung dengan penelitian lapangan ${ }^{8}$. Data primer diambil dari peraturan perundangan mengenai wakaf dan contoh kasus sengketa wakaf. Adapun data sekunder diambil dari penelitian-penelitian dan pendapat hukum tentang sengketa wakaf. Data yang didapatkan kemudian dianalisa secara kualitatif untuk mendapatkan gambaran umum mengenai penyelesaian sengketa wakaf melalui jalur litigasi dan non-litigasi.

\section{RUMUSAN MASALAH}

1. Bagaimana contoh kasus sengketa wakaf di Indonesia?

2. Bagaimana proses penyelesaian sengketa wakaf di Indonesia baik dari jalur litigasi maupun non-litigasi

\footnotetext{
8 Ahmad Zuhdi Muhdlor, "Perkembangan Metodologi Penelitian Hukum," Jurnal Hukum dan Peradilan 1, no. 2 (2012): 198.
} 
sesuai peraturan perundangan yang berlaku?

\section{TUJUAN PENELITIAN}

1. Untuk menganalisa bagaimana contoh kasus sengketa wakaf di Indonesia.

2. Untuk menganalisa bagaimana proses penyelesaian sengketa wakaf di Indonesia baik dari jalur litigasi maupun non-litigasi sesuai peraturan perundangan yang berlaku.

\section{METODE PENELITIAN}

Riset ini adalah penelitian kombinasi antara penelitian hukum normatif dan empiris. Metode empiris digunakan untuk menganalisa contoh kasus sengketa wakaf, sedangkan metode normatif untuk menganalisa peraturan perundangan tentang penyelesaiannya.

Data primer bersumber dari contoh kasus sengketa wakaf untuk kepentingan data empirisnya, dan peraturan perundangan mengenai wakaf sebagai bahan hukumnya yang diantaranya terdiri dari:

1. Peraturan Mahkamah Agung Nomor 1 Tahun 2008 tentang Prosedur Mediasi di Pengadilan

2. Peraturan Pemerintah Nomor 28 Tahun 1977 Tentang Perwakafan Tanah Milik.
3. Undang-Undang Nomor 41 Tahun 2004 Tentang Wakaf

4. Undang-Undang Nomor 5 Tentang Peraturan Dasar Pokok-Pokok Agraria.

Adapun data sekunder berasal dari penelitian-penelitian dan pendapat hukum tentang sengketa wakaf. Data yang didapatkan kemudian dianalisa secara induktif, yaitu dengan melakukan generalisasi dari contoh sengketa wakaf yang bersifat kasuistik, agar bisa diterapkan pada kasus-kasus lainnya secara umum.

\section{PEMBAHASAN}

Contoh Kasus Persengketaan Harta Wakaf

Sebelum membahas lebih jauh mengenai persengketaan wakaf. Ada baiknya digambarkan terlebih dahulu beberapa kasus menyangkut persengketaan wakaf tersebut sebagai berikut ${ }^{9}$ :

1. Pengesahan Wakaf di Aceh

Seseorang berinisial DDA pada tahun 1922 mewakafkan sebidang tanah untuk dijadikan sebagai tempat pendidikan. Tanah tersebut terletak di Desa Paloh, Kemukiman SP. II. Kecamatan Peusangan, Kabupaten Aceh Utara. Dua bulan setelah diwakafkan di atas tanah tersebut dibangun

\footnotetext{
9 Jaih Mubarak, Wakaf Produktif (Bandung: Simbiosa Rekatama Media, 2008), 183.
} 
masjid dan kemudian diteruskan dengan pembangunan madrasah. Saat itu yang menjadi nazhir adalah HI, salah seorang anak DDA. HI memiliki anak yang berinisial JH. Setelah HI meninggal, JH mengklaim bahwa kakeknya tidak pernah mewakafkan tanah tersebut dengan alasan tanah itu tidak terdaftar sebagai tanah wakaf dalam pendaftaran wakaf di KUA setempat.

Atas dasar peristiwa ini, $\mathrm{MH}$ dan kawan-kawan mengajukan gugatan ke Pengadilan Agama Bireun untuk mengesahkan tanah wakaf yang dilakukan oleh DDA. Dengan mendatangkan saksisaksi akhirnya Pengadilan Agama Bireun mengabulkan gugatan tersebut. Keputusan ini dibuat Pengadilan Agama Bireun Nomor 319/1984 tertanggal 24 Desember 1984.

Karena tidak puas, pihak yang kalah mengajukan banding ke Pengadilan Tinggi Agama Banda Aceh. PTA Banda Aceh kemudian menerima banding tersebut dan memutuskan untuk memerintahkan Pengadilan Agama Bireun untuk membuka kembali sidang perkara wakaf tersebut. Namun pada akhirnya PTA menetapkan Putusan Nomor 20 Tahun 1985 dengan keputusan bahwa wakaf yang dilakukan DDA adalah sah.

2. Penukaran Tanah Wakaf di Aceh
Kasus dibawah ini diputuskan oleh Pengadilan Agama Lhoksukon Nomor 1/P/1990/PA-LSK tertanggal 20 Februari 1990.

HW dan kawan-kawan dari Desa Tanjung Ara, Kecamatan Tanah Jambo Aye, pada tahun 1926 telah mewakafkan sebidang tanah untuk kuburan dan tempat pendidikan agama Islam. Kemudian pada tahun 1971, MNA menukarkan tanah tersebut dengan tanah lain milik TA. Karena tanah tersebut berupa sawah dan kebun, maka sawah dikelola oleh masyarakan dan kebun diserahkan kepada TA untuk mengelolanya.

Setelah beberapa waktu ternyata diketahui bahwasanya TA tidak memfungsikan tanah tersebut sebagaimana mestinya sesuai dengan tujuan wakaf karena menurutnya tanah tersebut bukan tanah wakaf. Akhirnya setelah memeriksa bukti-bukti dan saksi-saksi dinyatakan oleh Pengadilan Agama Lhoksukon bahwa tanah terperkara merupakan tanah wakaf dari HW.

3. Penjualan Tanah Wakaf di Pontianak 10

RA pada tahun 2011 membeli sebidang tanah dari HB selaku wakil sejumlah ahli waris atas tanah milik SS yang telah meninggal. Namun di tengah-

\footnotetext{
${ }^{10}$ Rosyid Zayyat, Perkara Pembatalan Akta Ikrar Wakaf (Pengadilan Agama Pontianak 2012).
} 
tengah proses balik nama, salah satu ahli waris menemukan kopi berlegalisir dari akta ikrar wakaf atas tanah yang menjadi objek jual-beli. RA pun selaku pembeli merasa dirugikan karena telah melakukan pembayaran down payment kepada ahli waris. RA juga langsung melakukan penelusuran kepada pihak terkait untuk mendapatkan dokumen asli akta ikrar wakaf tersebut, diantaranya yaitu di Kantor KUA Kecamatan Pontianak Barat, Kantor Kementerian Agama Kota Pontianak, Kantor Kementerian Agama Provinsi Kalimantan Barat, Kantor Camat Pontianak Kota, Kantor Badan Pertanahan Nasional Kota Pontianak, dan ahli waris, namun tidak ada satupun yang memiliki maupun mengetahui keberadaan Akta Ikrar Wakaf asli ini.

Akhirnya RA pun mengajukan gugatan pembatalan akta ikrar wakaf ke Pengadilan Agama Pontianak, namun gugatan tersebut ditolak dengan alasan bahwa RA secara hukum tidak memiliki legal standing untuk melakukan gugatan terhadap akta ikrar wakaf ini. Majelis hakim berdasarkan Peraturan Pemerintah Nomor 28 Tahun 1977 Pasal 12 memutuskan bahwa pihak yang berhak menggugat akta ikrar wakaf tersebut adalah Nazir, Wakif, ahli waris Wakif, atau pejabat yang berwenang. Maka RA yang hanya berstatus sebagai pembeli tanah tidak termasuk ke dalam empat kategori tersebut.

\section{Penyebab Persengkataan Harta Wakaf}

Setelah mengetahui kasus diatas, maka selanjutnya dapat disimpulkan penyebab terjadinya kasus tersebut. Pada kasus pertama, JH mengklaim bahwasanya kakeknya tidak pernah mewakafkan tanah karena tanah tersebut tidak terdaftar dalam pendaftaran wakaf di KUA setempat. Memang pada tahun 1922, peraturan mengenai perwakafan masih begitu terbatas karena saat itu Indonesia sendiri belum merdeka dan masih dijajah oleh Belanda di bawah Sistem Politik Kolonial Etis ${ }^{11}$. Ibadah wakaf seringkali dilakukan hanya secara lisan dan cukup diketahui oleh penduduk ataupun lembaga tertentu tanpa perlu surat-menyurat apapun ${ }^{12}$. Namun setelah zaman mulai berubah dan tanah menjadi sebuah komoditi yang harganya sangat mahal ${ }^{13}$, akhirnya pembuktian berupa surat-menyurat dan

11 Ulil Absiroh, Isjoni, and Bunari, "Sejarah Pemahaman 350 Tahun Indonesia Dijajah Belanda," Jurnal Online Mahasiswa (JOM) Bidang Keguruan dan Ilmu Pendidikan 4, no. 1 (2017): 7.

12 Ahmad Syafiq, "Urgensi Pencatatan Wakaf Di Indonesia Setelah Berlakunya UU No. 41 Tahun 2014 Tentang Wakaf," ZISWAF: Jurnal Zakat dan Wakaf 2, no. 1 (2015): 176, http://journal.stainkudus.ac.id/index.php/Ziswaf/arti cle/view/1542.

${ }^{13}$ Martin Roestamy and Rita Rahmawati, "Model Pengembangan Paradigma Masyarakat Bagi Kepemilikan Rumah Yang Terpisah Dari Tanah," Mimbar Hukum-Fakultas Hukum Universitas Gadjah Mada 30, no. 2 (2018): 332. 
akta otentik menjadi sangat penting ${ }^{14}$. Pada kasus ini, masalah administratif yang menjadi akar persengketaan.

Kemudian pada kasus kedua, penukaran tanah wakaf juga menjadi masalah. Hal ini dikarenakan penukaran tersebut dilakukan tanpa prosedur hukum yang jelas. Akar persengketaan disini juga lagi-lagi masalah administratif.

Terakhir pada kasus ketiga, ketiadaan dokumen asli akta ikrar wakaf serta sikap ahli waris yang terlalu terburu-buru menjual tanah juga memicu persengketaan karena merugikan pihak pembeli. Seandainya dokumen asli disimpan dengan baik dan tersosialisasi secara menyeluruh kepada semua ahli waris tentu penjualan tanah wakaf tersebut tidak akan terjadi.

Maka berdasarkan ketiga kasus diatas, dapat disimpulkan bahwasanya penyebab utama persengketaan harta wakaf adalah masalah administratif. Terutama dalam masalah pertanahan yang saat ini memerlukan berbagai macam bukti otentik kepemilikan. Kesimpulan ini senada dengan riset ${ }^{15}$ yang menyebutkan bahwa tanah wakaf yang tidak memenuhi ketentuan administratif menimbulkan

14 Abdurrahman Wahid, Yunanto, and Marjo, "Alat Bukti Surat Dalam Penyelesaian Perkara Perdata Pada Pengadilan Negeri Temanggung (Studi Kasus Putusan No. 45/Pdt. g/2013/Pn Tmg)," Diponegoro Law Journal 5, no. 3 (2016): 1 .

${ }^{15}$ Nur Fadhilah, "Sengketa Tanah Wakaf Dan Strategi Penyelesaiannya," 82. ketidakpastian hukum terhadap status tanah tersebut.

\section{Penyelesaian Sengketa Harta Wakaf}

Dimulai pada tahun 70-an, masalah wakaf mulai menjadi pembicaraan di kalangan legislator Indonesia ${ }^{16}$. Hal ini disebabkan pemberlakuan Undang-Undang Nomor 5 Tahun 1960 Tentang Peraturan Dasar Pokok-Pokok Agraria yang mengatur mengenai kewajiban kepemilikan surat tanda bukti hak bagi pemilik tanah.

Memang pada waktu yang lampau, walaupun wakaf sudah menjadi salah satu kompetensi absolut Pengadilan Agama sejak tahun 1882 berdasarkan Staatsblad $1882 / 152^{17}$, namun peraturan wakaf tanah belum diatur secara tuntas sehingga berpotensi menimbulkan ketidakjelasan mengenai benda-benda yang telah diwakafkan. Bahkan kadang-kadang terjadi benda-benda yang diwakafkan itu seolaholah sudah menjadi hak milik nadzir.

Akhirnya dirumuskan Peraturan Pemerintah Nomor 28 Tahun 1977 Tentang Perwakafan Tanah Milik Pasal 12.

${ }^{16}$ Bashlul Hazami, "Peran Dan Aplikasi Wakaf Dalam Mewujudkan Kesejahteraan Umat Di Indonesia," 185.

17 Abdullah Tri Wahyudi, "Kewenangan Absolut Peradilan Agama Di Indonesia Pada Masa Kolonial Belanda Hingga Masa Pasca Reformasi," Jurnal Pemikiran dan Penelitian Sosial Keagamaan 7, no. 2 (2016): 289, http://journal.stainkudus.ac.id/index.php/Yudisia/art icle/view/2156. 
Dalam PP tersebut disebutkan bahwa penyelesaian persengketaan perwakafan tanah dilakukan oleh Pengadilan Agama setempat sesuai dengan peraturan perundang-undangan yang berlaku ${ }^{18}$.

Kemudian pada tanggal 10 Juni 1991, diterbitkan Kompilasi Hukum Islam Buku III tentang Hukum Perwakafan. Dalam buku tersebut tidak hanya sengketa wakaf tanah, namun segala persoalan yang menyangkut benda wakaf dan Nazhir diajukan kepada Peradilan Agama setempat ${ }^{19}$.

Perkembangan terakhir mengenai undang-undang perwakafan dilaksanakan pada tahun 2004 melalui Undang-Undang Nomor 41 Tahun 2004 Tentang Wakaf. Dalam undang-undang tersebut dinyatakan bahwa:

1. Penyelesaian sengketa perwakafan ditempuh melalui musyawarah untuk mencapai mufakat.

2. Apabila penyelesaian sengketa sebagaimana dimaksud pada ayat satu (1) tidak berhasil, sengketa dapat diselesaikan melalui mediasi, arbitrase, atau pengadilan.

Sesuai dengan undang-undang di atas, penyelesaian sengketa harta wakaf ditempuh dengan beberapa tahapan yang seyogyanya dilakukan secara stratifikatif sebagai berikut:

${ }^{18}$ Muhammad Daud Ali, Sistem Ekonomi Islam (Jakarta: UI-Press, 1988), 122.

19 Cik Hasan Bisri, Kompilasi Hukum Islam Dan Peradilan Agama Dalam Sistem Hukum Nasional (Jakarta: Logos Wacana Ilmu, 1999), 215.
1. Melalui musyawarah untuk mencapai mufakat. Musyawarah dapat dilakukan secara berjenjang sebagaimana model musyawarah bertingkat dalam menyelesaikan sengketa perkawinan pada masyarakat Batak Muslim di Tapanuli Bagian Selatan 20. Musyawarah untuk menangani sengketa juga dapat dilakukan secara sederhana sebagaimana ajaran alQur'an mengenai upaya islah terhadap pertengkaran suami-istri dalam surah an-Nisa ayat 35 yang berbunyi:

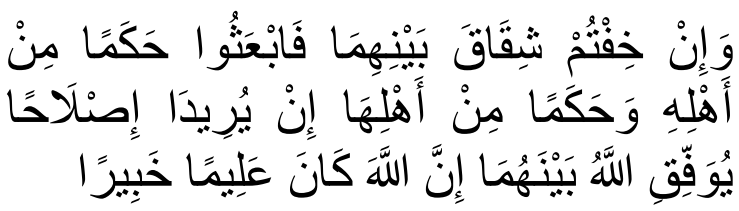
Artinya: "Dan jika kamu khawatirkan ada persengketaan antara keduanya, maka kirimlah seorang hakam (juru pendamai) dari keluarga laki-laki dan seorang hakam dari keluarga perempuan. Jika kedua orang hakam itu bermaksud mengadakan perbaikan, niscaya Allah memberi taufik kepada suami-isteri itu. Sesungguhnya Allah Maha Mengetahui lagi Maha Mengenal."

2. Jika musyawarah tidak menghasilkan kesepakatan, maka sengketa dapat diselesaikan melalui mediasi dengan bantuan pihak ketiga yang disepakati

20 Anwar Sadat Harahap, "Sistem Musyawarah Dalam Penyelesaian Sengketa Perusakan Hutan Pada Masyarakat Adat Dalihan $\mathrm{Na}$ Tolu," in Seminar Nasional Hasil Penelitian 2018 (Medan: Universitas Muslim Nusantara Al Washliyah, 2018), 295-298, http://eprosiding.umnaw.ac.id/index.php/penelitian/article/ view/118 
para pihak yang bersengketa sebagai penengah atau mediator ${ }^{21}$. Mediasi yang dimaksud disini tentu bukan termasuk mediasi yang diselenggarakan oleh Pengadilan Agama sebelum sidang pertama. Sebab begitu surat gugatan telah masuk ke Pangadilan Agama, maka secara otomatis berarti para pihak memilih jalur litigasi untuk menyelesaikan sengketanya.

3. Apabila mediator ternyata juga tidak memberikan keputusan yang memuaskan salah satu pihak, jalan selanjutnya yang bisa ditempuh melalui arbitrase dengan bantuan lembaga BASYARNAS (Badan Arbitrase Syariah Nasional) sebagai lembaga islah yang mampu menyelesaikan sengketa perdata di luar peradilan umum. Sayangnya metode penyelesaian melalui jalur arbitrase ini jarang sekali dilakukan dalam sengketa wakaf. Sebab arbitrase lebih sering digunakan dalam penyelesaian kasus sengketa di bidang perdagangan ${ }^{22}$. Padahal hasil putusan

\footnotetext{
${ }^{21}$ Syufa'at, "Penerapan Prosedur Mediasi Dalam Penyelesaian Sengketa Wakaf Di Pengadilan Agama," 31.

22 Dewi Hendrawati and Islamiyati, "Penyelesaian Sengketa Tanah Wakaf Yang Tidak Tersertifikasi Di Wilayah Pesisir Utara Jawa Tengah," Masalah-Masalah Hukum 47, no. 1 (2018): 77.
}

arbitrase bersifat mengikat ${ }^{23}$ dan memutus wewenang Pengadilan Agama untuk menangani persengketaan para pihak yang telah terikat oleh putusan arbitrase tersebut 24

4. Jika ketiga jalur non-litigasi diatas berakhir kepada kebuntuan, maka satu-satunya jalan yang tersisa adalah jalur litigasi yaitu melalui Pengadilan Agama. Pengadilan Agama dalam menangani sengketa wakaf ini menggunakan prosedur dan ketentuan hukum acara perdata yang juga berlaku di lingkungan peradilan umum 25, dimana setelah gugatan dilayangkan hakim wajib menyelenggarakan mediasi sebagai bentuk upaya mendamaikan kedua belah. Hal ini sebagaimana diatur dalam Peraturan Mahkamah Agung Nomor 1 Tahun 2008 tentang Prosedur Mediasi di Pengadilan. Apabila mediasi yang dipimpin oleh hakim ini tidak berhasil mendamaikan kedua

${ }^{23}$ Syufa'at, "Penerapan Prosedur Mediasi Dalam Penyelesaian Sengketa Wakaf Di Pengadilan Agama," 28

24 Jamaludin, "Penyelesaian Sengketa Wakaf Melalui BASYARNAS," Misykat al-Anwar Jurnal Kajian Islam dan Masyarakat 30, no. 1 (2019): https://jurnal.umj.ac.id/index.php/MaA16/article/vi ew/3610.

25 Adi Nur Rohman and Sugeng, "Penyelesaian Sengketa Wakaf Di Pengadilan Agama Jakarta Selatan," IJTIHAD 12, no. 1 (2018): 20 . 
pihak, maka barulah sidang dapat dilanjutkan dengan agenda pembacaan surat gugatan, jawaban, jawab menjawab, pembuktian dan kesimpulan pihak ${ }^{26}$.

Perlu diperhatikan bahwasanya ketika persengketaan sudah mencapai tingkat pengadilan maka segalanya akan menjadi berbelit-belit dan sulit karena pada saat itu para pihak akan dihadapkan kepada masalah gugatan, penggugat, tergugat, saksi, pengakuan, bahkan sumpah ${ }^{27}$. Penyelesaian sengketa melalui jalur-jalur sebelumnya jauh lebih efisien dan efektif. Oleh karena itu hendaknya gugatan hanya diajukan jika tidak ada cara lain untuk menyelesaikan sengketa.

\section{PENUTUP}

Kasus-kasus sengketa wakaf yang terjadi di Aceh dan Pontianak di atas menunjukkan bahwa penyebab utama sengketa wakaf tanah adalah masalah administratif, yaitu dikarenakan wakaf tanah dilakukan tanpa proses administrasi yang benar sesuai peraturan perundangan. Adapun proses penyelesaian sengketa wakaf tersebut berdasarkan UndangUndang Nomor 41 Tahun 2004 Tentang

\footnotetext{
${ }^{26}$ Syufa'at, "Penerapan Prosedur Mediasi Dalam Penyelesaian Sengketa Wakaf Di Pengadilan Agama," 33.

27 Muhammad Abid Abdullah al-Kabisi, Hukum Wakaf (Jakarta: IIMaN, 2003), 579.
}

Wakaf terdiri dari empat tahapan dari jalur non-litigasi ke jalur litigasi, yaitu musyawarah, mediasi, aribitras, dan upaya terakhir yaitu melalui pengadilan agama. Penyelesaian sengketa melalui jalur nonlitigasi tentu jauh lebih efektif dan efisien dibandingkan jalur litigasi karena tidak memakan banyak waktu dan biaya. Oleh karena itu seyogyanya jalur litigasi hanya digunakan sebagai alternatif terakhir jika cara-cara lainnya gagal untuk menyelesaikan sengketa.

Riset ini hanya mendeskripsikan sengketa wakaf dari sisi penyelesaian melalui jalur non-litigasi dan litigasinya secara umum saja. Oleh karena itu riset lain untuk memperoleh informasi lebih detail mengenai masing-masing cara penyelesaian dalam memproses sengketa wakaf tersebut mungkin juga perlu untuk dikaji, sehingga masyarakat dapat memperoleh gambaran yang lebih utuh mengenai proses penyelesaian sengketa wakaf, dan dapat memilih alternatif penyelesaian yang lebih cocok dengan kasus yang mereka hadapi.

\section{DAFTAR PUSTAKA}

Abdullah Tri Wahyudi. "Kewenangan Absolut Peradilan Agama Di Indonesia Pada Masa Kolonial Belanda Hingga Masa Pasca Reformasi." Jurnal Pemikiran dan Penelitian Sosial Keagamaan 7, no. 
2

(2016).

http://journal.stainkudus.ac.id/index .php/Yudisia/article/view/2156.

Adi Nur Rohman, and Sugeng. "Penyelesaian Sengketa Wakaf Di Pengadilan Agama Jakarta Selatan." IJTIHAD 12 , no. 1 (2018): 20-43.

Ahmad Zuhdi Muhdlor. "Perkembangan Metodologi Penelitian Hukum.” Jurnal Hukum dan Peradilan 1, no. 2 (2012).

Amirul Bakhri, and Srifariyati. "Peran Wakaf Produktif Dalam Pemberdayaan Ekonomi." Madaniyah 1, no. 12 (2017). https://journal.stitpemalang.ac.id/in dex.php/madaniyah/article/view/67.

Anwar Sadat Harahap. "Sistem Musyawarah Dalam Penyelesaian Sengketa Perusakan Hutan Pada Masyarakat Adat Dalihan $\mathrm{Na}$ Tolu." In Seminar Nasional Hasil Penelitian 2018. Medan: Universitas Muslim Nusantara Al Washliyah, 2018. http://eprosiding.umnaw.ac.id/index.php/p enelitian/article/view/118.

Bashlul Hazami. "Peran Dan Aplikasi Wakaf Dalam Mewujudkan Kesejahteraan Umat Di Indonesia." Analisis 16, no. 1 (2016). http://ejournal.radenintan.ac.id/inde x.php/analisis/article/view/742.

Cik Hasan Bisri. Kompilasi Hukum Islam Dan Peradilan Agama Dalam Sistem Hukum Nasional. Jakarta: Logos Wacana Ilmu, 1999.

Hendrawati, Dewi, and Islamiyati. "Penyelesaian Sengketa Tanah Wakaf Yang Tidak Tersertifikasi Di Wilayah Pesisir Utara Jawa Tengah.” Masalah-Masalah Hukum 47, no. 1 (2018): 71-80.

Ibrahim Siregar. "Penyelesaian Sengketa Wakaf Di Indonesia: Pendekatan Sejarah Sosial Hukum Islam.” MIQOT 36, no. 1 (2012).

Jaih Mubarak. Wakaf Produktif. Bandung: Simbiosa Rekatama Media, 2008. Jamaludin. "Penyelesaian Sengketa Wakaf Melalui BASYARNAS." Misykat al-Anwar Jurnal Kajian Islam dan Masyarakat 30, no. 1 (2019). https://jurnal.umj.ac.id/index.php/ MaA16/article/view/3610.

Muhammad Abid Abdullah al-Kabisi. Hukum Wakaf. Jakarta: IIMaN, 2003.

Muhammad Daud Ali. Sistem Ekonomi Islam. Jakarta: UI-Press, 1988.

Muslim bin Hajjaj. Sahih Muslim. Beirut: Dar al-Kutub al-Ilmiyah, 1991. 
Nur Fadhilah. "Sengketa Tanah Wakaf Dan Strategi Penyelesaiannya." de Jure 3, no. 1 (2011).

Roestamy, Martin, and Rita Rahmawati.

"Model Pengembangan Paradigma

Masyarakat Bagi Kepemilikan

Rumah Yang Terpisah Dari

Tanah." Mimbar Hukum-Fakultas

Hukum Universitas Gadjah Mada

30, no. 2 (2018): 331-345.

Rosyid Zayyat. Perkara Pembatalan Akta

Ikrar Wakaf (Pengadilan Agama

Pontianak 2012).

Syafiq, Ahmad. "Urgensi Pencatatan

Wakaf Di Indonesia Setelah

Berlakunya UU No. 41 Tahun 2014

Tentang Wakaf." ZISWAF: Jurnal

Zakat dan Wakaf 2, no. 1 (2015).

http://journal.stainkudus.ac.id/index

.php/Ziswaf/article/view/1542.

Syufa'at. "Penerapan Prosedur Mediasi

Dalam Penyelesaian Sengketa

Wakaf Di Pengadilan Agama."

Volksgeist: Jurnal Ilmu Hukum dan

Konstitusi 1, no. 1 (2018): 21-36.

Ulil Absiroh, Isjoni, and Bunari. "Sejarah

Pemahaman 350 Tahun Indonesia

Dijajah Belanda." Jurnal Online Mahasiswa (JOM) Bidang

Keguruan dan Ilmu Pendidikan 4, no. 1 (2017): 1-15.

Upi Komariah. "Penyelesaian Sengketa

Wakaf Di Pengadilan Agama."
Jurnal Hukum dan Peradilan 3, no. 2 (2014).

Wahid, Abdurrahman, Yunanto, and Marjo. "Alat Bukti Surat Dalam Penyelesaian Perkara Perdata Pada Pengadilan Negeri Temanggung (Studi Kasus Putusan No. 45/Pdt. g/2013/Pn Tmg).” Diponegoro Law Journal 5, no. 3 (2016): 1-6.

Peraturan Mahkamah Agung Nomor 1 Tahun 2008 tentang Prosedur Mediasi di Pengadilan

Peraturan Pemerintah Nomor 28 Tahun 1977 Tentang Perwakafan Tanah Milik.

Undang-Undang Nomor 41 Tahun 2004 Tentang Wakaf

Undang-Undang Nomor 5 Tentang Peraturan Dasar Pokok-Pokok Agraria. 